\title{
LIVA ROTKALE
}

University of Latvia, Latvia

\section{A TERMINOLOGICAL PUZZLE IN ARISTOTLE'S} ARS RHETORIC A, III 2, 1404b37-1405a2

\section{Brief summary}

There is a perplexing sentence in $R h$. III 2, 1404b37-1405a2, which seems to imply that technical terms synōnyma and, by analogy, homōnyma are used differently in different contexts, i.e. in the Rhetoric these terms pertain to words, but in the Categories they designate things. Thus, it creates the impression that Aristotle has changed his mind with respect to the meaning of these terms. The interpretation, which is offered by the majority of translators and commentators, appears to embrace this conclusion. It is reinforced by the entry on synōnymos in the Greek-English Lexicon. The aim of the article is to explain the perplexing sentence in such a way that it is compatible with the definitions of synōnyma and homōnyma given in the Categories.

Keywords: homōnymiai, synōnymiai, synōnyma, homōnyma, Rhetoric, Categories.

Terminological precision and coherence has always been considered to be a virtue. The sentence at $R h$. III 2, 1404b37-1405a2 presents a terminological puzzle. It is a challenge to interpret this sentence in such a way that the virtue of precision and coherence survives intact in Aristotle. In this article, I will attempt to provide an interpretation of the sentence at $R h$. III 2, 1404b37-1405a2, according to which this sentence is compatible with Aristotle's terminology in the Categories. I will contrast my interpretation with the standard interpretation and address certain problems, which must be circumvented, if my interpretation is to hold as a plausible reading.

I

Let us look at the perplexing sentence at $R h$. III 2, 1404b37-1405a2:

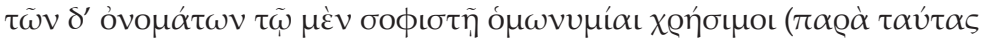

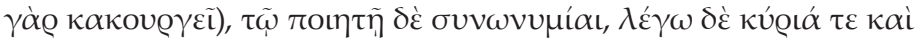




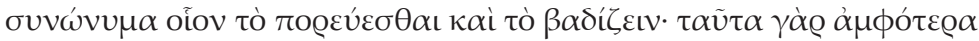

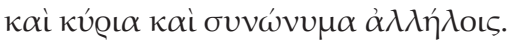

The standard interpretation, which is exhibited by the majority of translations and commentaries (e.g. Cope 1877, Vol. 3, 19; Freese 1926, 355; Kennedy 2008, 200; Rapp 2002, 839-840), is manifest, for example, in the following translation:

The kind of words useful to a sophist are homonyms (by means of these he does his dirty work), to a poet synonyms. By words that are both in their prevailing meaning and synonymous I mean, for example, go and walk; for when used in their prevailing sense these are synonymous with each other.

(Kennedy 2008, 200)

The standard interpretation embraces the following points:

(1) There are two kinds of words - homōnymiai and synōnymiai.

(2) The words go and walk are kyria and synonyma with each other.

(3) Being a synōnymon is a property of words. (From (2))

(4) Synōnymiai are synōnyma. (From (1) and (3))

(5) Homōnymiai are homōnyma. (By analogy to (4))

(6) Being a homōnymon is a property of words. (By analogy to (3))

According to the standard interpretation, synōnyma and also, by analogy, homōnyma (a term which is not mentioned in the passage, but which suggests itself due to mentioning of homōnymiai) are understood as pertaining to words, synōnymiai (synonyms) and homōnymiai (homonyms) respectively. What is perplexing is that the conception of synonyma and homōnyma as pertaining to words appears to contradict Aristotle's definitions of synōnyma and homōnyma in the Categories (see Cat. 1, 1a6-8 and 1, 1a1-3), where synōnyma and homonyma are things. Thus, the passage at $R h$. III 2, 1404b37-1405a2 implies that Aristotle has changed his mind with respect to the meaning of synonyma and homōnyma.

This assumption appears to coincide with, and is reinforced by, the information that we find in the Greek-English Lexicon entry on

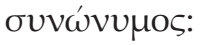

in the Logic of Arist. $\sigma v v \omega v v \mu \alpha$ are things having the same name and the same nature and definition, Cat. 1a6 [...]

in Rhet. $\tau \dot{\alpha} \mathrm{s}$. are synonyms, words having different forms but the same sense,

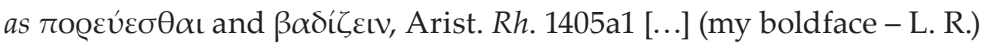


In favor of the latter meaning of synonyma, the dictionary gives reference to $R h$. 1405a1, which is a locus in the passage that I am discussing here. It should be noted that there is one slight but important difference between the standard interpretation and the entry. According to the standard interpretation, the words go and walk are synonymous with each other, but in the entry these words are synonyms. The standard interpretation takes synōnyma to be a property of synōnymiai, whereas the entry treats synōnyma (in Rh. 1405a1) as identical to synōnymiai.

The Greek-English Lexicon entry on ó $\mu \omega v v \mu o s$ does not contain a double meaning. It is stated that homōnyma are things:

in the Logic of Arist., $\tau \dot{\alpha}$ o. are things having the same name but different natures and definitions, things denoted by equivocal or ambiguous words, Cat. 1a1 [...] (my boldface - L. R.)

The explanation of the meaning of homonyma in Aristotle is based on the reference to the Categories suggesting that this is the core meaning of homōnyma. Had Aristotle mentioned homōnyma in the puzzling passage at $R h$. III 2, 1404b37-1405a2, the entry probably would have contained the other meaning of homōnyma as equivocal or ambiguous words.

I I

Let us focus on the case of synōnyma. The Categories contain the following definition:

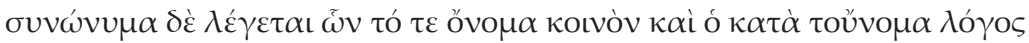

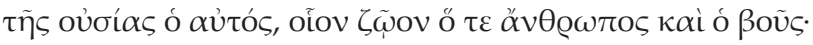

When things have the name in common and the definition of being which corresponds to the name is the same, they are called synonymous. Thus, for example, both a man and an ox are animals.

(Cat. 1, 1a6-8, trans. Ackrill 1963)

The example Aristotle gives here - that a man and an ox are synonymous things - seems to conflict with the example in the fragment of the Rhetoric, where it is said that go and walk are synōnyma, if synōnyma are taken to be synonymous words. How are we supposed to understand the statement that go and walk are synonymous? 
One might immediately point out that the apparent conflict provides evidence for the hypothesis that in the Rhetoric Aristotle has decided to change or perhaps slipped into changing the meaning of synonyma, so that now they are words, not things. And a similar change in meaning has happened to homōnyma.

Let us consider again the statement at 1405a1 that go and walk are synonymous. It is worth looking at the Greek phrase, as the phrase

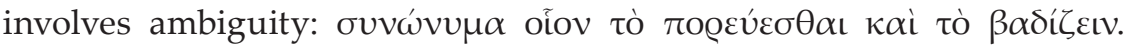

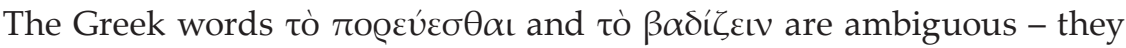
may refer to things or to words, since neuter article tó can serve various tasks: 1) when tó is added to infinitive or to any phrase, we get a neuter noun, which as any other noun refers to a thing; 2) the neuter article tó can serve the same function that quotation marks serve in English, and in that case, the phrase beginning with tó refers to a word. Thus,

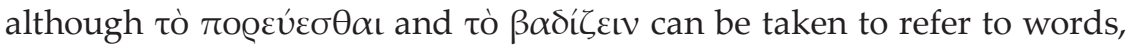
go and walk, they need not be taken as such; they can be taken as referring to things themselves, to going and walking. In that case, the statement at $1405 \mathrm{a} 1$ is that going and walking are synonymous things. This accords well with Aristotle's example of synōnyma in Cat. 1, 1a3, where a man and an ox are synonymous things. Hence, no change seems to be in meaning of synonyma, and the assumption that there has been a change may not be true.

\section{III}

However, there is a serious obstacle to my interpretation. It is the oc-

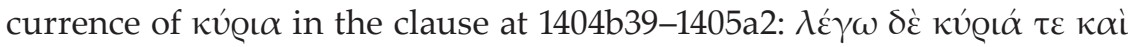

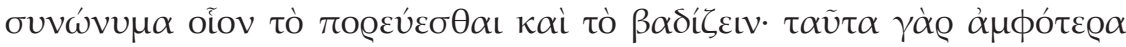

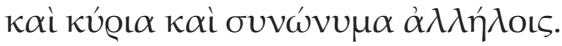

At an earlier passage, кú

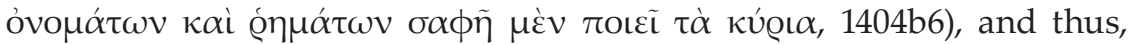
here the phrase кú@ı $\alpha$ óvó $\mu \alpha \tau \alpha$ also suggests itself. The whole context is about names, and it is very similar to the discussion about names

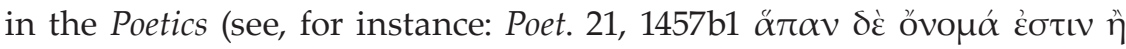

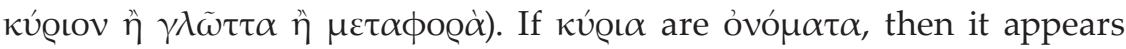
that $\sigma v v \omega v v \mu \alpha$ are also óvó $\mu \alpha \tau \alpha$. If $\kappa v ́ \varrho \iota \alpha$ were not mentioned at 1404b39-1405a2, we could easily read the sentence in such a way that $\tau$ ò

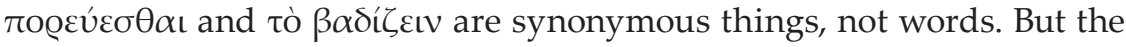




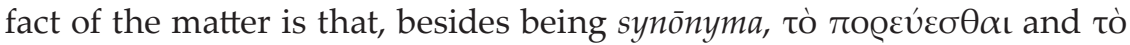
$\beta \alpha \delta i \zeta c\llcorner v$ are also kú

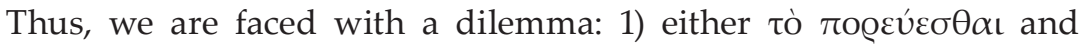

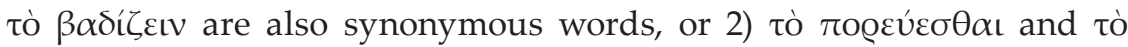
$\beta \alpha \delta i \zeta \varepsilon เ V$ are ambiguous in one and the same sentence, referring both to things themselves, i.e. to going and walking, and to words, i.e. to go and walk. If we choose the first horn of the dilemma, then we have to conclude that Aristotle does not use synonyma uniformly and he is fluctuating between synōnyma as pertaining to words and synōnyma as things. That would, in turn, suggest that the assumption that there has been a change of Aristotle's mind is true. If we choose the second horn of the dilemma, then we have to conclude that the clause at 1404b39-1405a2 is elliptical. It contains two distinct propositions, one about words

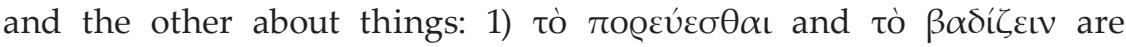

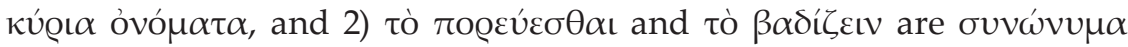

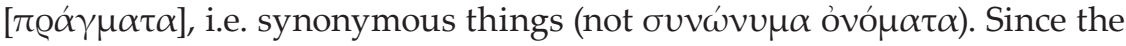
first horn of the dilemma leads to the conclusion that there has been a change of Aristotle's mind, I opt for the second.

\section{V}

Now, the troubles with the sentence at $R h$. III 2, 1404b37-1405a2 are not over yet. The source of trouble lies at the beginning of the sentence, where we can read that homōnymiai and synōnymiai are words ( $\tau \tilde{\omega} v \delta^{\prime}$

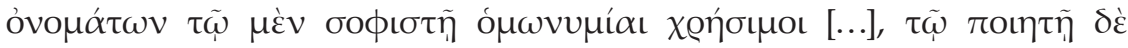
$\sigma v v \omega v v \mu i \alpha \mathrm{l}, 1404 \mathrm{~b} 37-39)$. At this point, our opponent can say that this is again an evidence of a change of Aristotle's mind with respect to the meaning of synōnyma and also of homonyma, since the terms synōnymiai and synōnyma, on the one hand, and homōnymiai and homōnyma, on the other, seem to be interchangeable.

According to my interpretation, the statement that homōnymiai and synōnymiai are words is no evidence for a change of Aristotle's mind; on the contrary, this is evidence for stability. I claim that Aristotle reserves different terms for different ideas, namely, synōnymiai and homōnymiai are words (i.e. synonyms and homonyms), whereas synōnyma and homōnyma are things (i.e. synonymous things and homonymous things).

The evidence for the fact that Aristotle can be interpreted as drawing distinctions between synōnymiai (synonyms) vs. synōnyma (synonymous 
things), and between homōnymiai (homonyms) vs. homōnyma (homonymous things) can be found in Porphyry's (Поффúpıos, c. 234 - c. 305 AD) commentary on the Categories. There is a discussion of homonyma, and a distinction between homōnyma and homōnymia is clearly made. Let us first look at Aristotle's definition of homōnyma in the Categories:

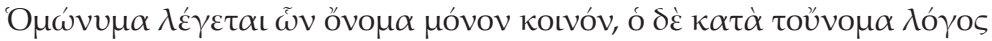

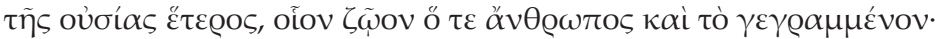

When things have only a name in common and the definition of being which corresponds to the name is different, they are called homonymous. Thus, for example, both a man and a picture are animals.

(Cat. 1, 1a1-3, trans. Ackrill 1963)

In Porphyry's commentary on the Categories we are told that homōnymia is a word, whereas homōnyma are things (ó $\omega \omega v v \mu i ́ \alpha \mu \grave{\varepsilon} v$ $\phi \omega v \eta ́$, ó $\mu \omega v v \mu \alpha \delta \dot{\varepsilon} \tau \dot{\alpha} \pi \varrho \alpha ́ \gamma \mu \alpha \tau \alpha$, In Cat. 61.14). Porphyry also says that homōnymia is dependent on homōnyma, since

[..] what produces [homōnymia] in words is not the character of the expression itself, but rather things are found to be different and in no way have anything in common yet acquire one and the same expression as their name.

(In Cat. 61.17-19, transl. by Strange, my changes in brackets - L. R.)

It is the things, homōnyma, that bring about homōnymia in words. However, Porphyry does not quite explain how one gets form things to words. Since homonymos means having the same name, not being the same name (this point is taken from Barnes 1971, 71-72), homōnymia should be a property of things that have only a name in common, not a name that refers to different things (i.e. an equivocal word).

A plausible explanation of the way one gets form things to words could be the following. Aristotle needed a term to describe the other side of the coin: if there are things such that they have the same name, one should be able to say that there is also the name such that it is had by the things. It is reasonable to speculate that, in order to avoid confusion, Aristotle has reserved homōnyma for things, and homōnymiai for words. Thus, although homonnymia primarily characterizes the property exhibited by homōnyma, by an extension of meaning, homōnymia designates the word itself which homōnyma have in common. Thereby it is 
understandable why Porphyry can say that homōnymia is a word, but homōnyma are things.

The same reasoning applies to synōnymia and synōnyma. Thus, we can say that synonyma have synōnymia as a property and as a word, i.e. synōnyma exhibit the property of synōnymia, and, in turn, synōnymia is the word, which is shared by synōnyma, viz. synōnymia is a name that refers to things with similar natures and definitions.

V

Let us revisit the fragment at $R h$. III 2, 1404b37-1405a2 in light of the considerations drawn from the previous investigation. The interpretation that we can now offer is this:

(1) There are two kinds of words - homōnymiai and synōnymiai.

(2) Go and walk are kyria and synōnyma with each other.

(3) Synōnyma are things. (According to Cat. 1, 1a6-8)

(4) Kyria are words. (According to Rh. 1404b6)

(5) As words, go and walk are kyria. (From (2) and (4))

(6) As things, go and walk are synōnyma. (From (2) and (3))

(7) Homōnyma are things. (According to Cat. 1, 1a1-3)

(8) Homōnymia is shared by homōnyma. (According to Porph. In Cat. 61.17-19)

(9) Synōnymia is shared by synōnyma. (By analogy to (8))

In line with this interpretation, we can offer a slightly but crucially different translation of $R h$. III 2, 1404b37-1405a2:

The kind of words useful to a sophist are homonyms (by means of these he does his dirty work), to a poet synonyms. I mean, for example, go and walk are both words in their prevailing meaning and synonymous things, for both of them are words in their prevailing meaning and things that are synonymous with each other.

Hence, I propose a different interpretation of the passage at $R h$. III 2, 1404b37-1405a2, according to which this passage is not in conflict with the definitions of synōnyma and of homōnyma in the Categories. My interpretation has the advantage of preserving terminological precision and coherence in Aristotle. 


\section{SOURCES}

1. Aristotelis ars rhetorica. W. D. Ross (ed.). Oxford: Clarendon Press, 1964.

2. Aristotelis categoriae et liber de interpretatione. L. Minio-Paluello (ed.). Oxford: Clarendon Press, 1966.

3. Aristotelis de arte poetica liber. R. Kassel (ed.). Oxford : Clarendon Press, 1968.

4. Porphyrii isagoge et in Aristotelis categorias commentarium. A. Busse (ed.). Vol. 4.1. Commentaria in Aristotelem Graeca. Berlin: Reimer, 1887.

\section{LITERATURE}

1. A Greek-English Lexicon. H. G. Liddell, R. Scott, H. S. Jones, R. McKenzie (eds.). Oxford: Clarendon Press; New York : Oxford University Press, 1996.

2. Barnes, Jonathan. Homonymy in Aristotle and Speusippus. The Classical Quarterly 21(1), 1971, 65-80.

3. Cope, Edward Meredith. The Rhetoric of Aristotle, with a Commentary, 3 vols. J. E. Sandys (ed.). Cambridge : Cambridge University Press, 1877.

4. Freese, Hohn Henry. Aristotle, with an English Translation: the "Art" of Rhetoric. London : W. Heinemann; New York : G. P. Putnam's Sons, 1926.

5. Kennedy, George A. Aristotle, On Rhetoric. A Theory of Civic Discourse, Translated, with Introduction, Notes and Appendices. New York, Oxford : Oxford University Press, 2007.

6. Rapp, Christof. Aristoteles, Rhetorik. Übersetzung und Kommentar, 2 Bde. Aristoteles, Werke in deutscher Übersetzung. H. Flashar (Hrsg.). Berlin: Akademie Verlag, 2002.

7. Strange, Steven K. Porphyry, On Aristotle's Categories. Ithaca, NY : Cornell University Press, 1992.

\section{TERMINOLOG̣ISKA MĪKLA ARISTOTEḶA DARBĀ RETTORIKA, III 2, 1404B37-1405A2}

\section{KOPSAVILKUMS}

Aristoteḷa darbā Rētorika (Rh. III 2, 1404b37-1405a2) atrodams mulsinošs teikums, kas šḳietami paredz, ka visai tehniskie termini synōnyma un pēc analoǵijas arī homōnyma - tiek atšḳirīgi lietoti dažādos kontekstos, proti, darbā Rētorika šie termini attiecas uz vārdiem, bet darbā Katēgorijas tie apzīmē lietas. Rodas iespaids, ka darbā Rētorika Aristotelis ir mainījis šo terminu nozīmi. Standarta interpretācija, t. i., interpretācija, ko piedāvā lielākā tulkotāju un komentētāju daḷa, ietver šādu secinājumu, kas šḳiet vēl neapstrīdamāks, ielūkojoties grieḳu-angḷu leksikona (Greek-English Lexicon) šḳirklī par synōnymos. Raksta mērḳis ir izskaidrot Aristoteḷa darbā Rētorika atrodamo mulsinošo teikumu tā, ka tas ir savienojams ar synōnyma un homōnyma definīciju, kas sniegtas darbā Katēgorijas. Standarta interpretācijas vietā autore piedāvā atšḳirīgu 
mulsinošā teikuma interpretāciju saskaṇā ar izpētes gaitā sasniegtajiem apsvērumiem: pastāv divu veidu vārdi - homōnymiai un synōnymiai; iet un staigāt ir kyria un synōnyma; synōnyma ir lietas; kyria ir vārdi; ja iet un staigāt tiek saprasti kā vārdi, tie ir kyria; bet, ja iet un staigāt tiek saprasti kā lietas, tie ir synōnyma; homōnyma ir lietas; homōnyma līdzdala homōnymia; synōnyma līdzdala synōnymia. 